\title{
Seamless Learning: A Scoping Systematic Review Study
}

\author{
Gürhan Durak ${ }^{1} \rtimes$ \\ Serkan Çankaya ${ }^{2}$ \\ Balikesir University, Turkey \\ Email:gurhandurak@balikesir.edu.tr
}

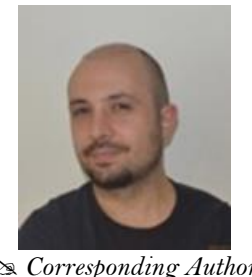

( Corresponding Author)

\begin{abstract}
In recent years, a new concept called seamless learning has appeared. This concept depends on the premise that learning should be maintained without interruption in different environments. Seamless learning is also important not only for meeting the expectations of the new generation whose life styles and learning needs are different but also for supporting the new paradigms in education. In this respect, the present study aimed to demonstrate the results of content analysis on the articles related to concept of Seamless Learning in Scopus database between 2009 and 2018. A total of 58 papers were examined to determine the concept list, top journal list, most cited papers, research methods and models, participants, data collection tools and variables in these articles. The study is considered to be important as no detailed content analysis has been conducted on the concept of seamless learning concept. The research results revealed a considerable increase in the number of studies on the concept of seamless learning by year. Singapore was the leading country in seamless learning research. It was seen in these studies that conceptual/descriptive methods were prominent as the research methods; that K-12 students were preferred more as participants; and that the most common data collection tools included interview and academic achievement tests. Lastly, in the studies examined, academic performance and perception were among the most popular dependent variables.
\end{abstract}

Keywords: Seamless learning, Research trends, Systematic review, Content analysis.

JEL Classification: Learning, Technological change.

Citation | Gürhan Durak; Serkan Çankaya (2018). Seamless Learning: A Scoping Systematic Review Study. Journal of Education and e-Learning Research, 5(4): 225-234.

History:

Received: 3 September 2018

Revised: 8 October 2018

Accepted: 9 November 2018

Published: 4 December 2018

Licensed: This work is licensed under a Creative Commons

Attribution 3.0 License $(\mathrm{cc})$ )

Publisher: Asian Online Journal Publishing Group
Contribution/Acknowledgement: Both authors contributed to the conception and design of the study.

Funding: This study received no specific financial support.

Competing Interests: The authors declare that they have no conflict of interests.

Transparency: The authors confirm that the manuscript is an honest, accurate, and transparent account of the study was reported; that no vital features of the study have been omitted; and that any discrepancies from the study as planned have been explained.

Ethical: This study follows all ethical practices during writing.

\section{Contents}

1. Introduction

2. Related Literature

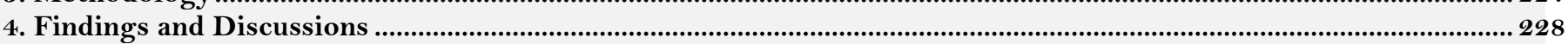

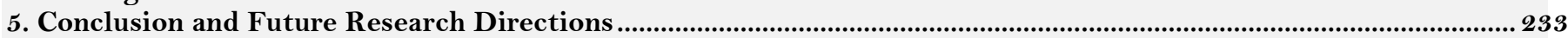

References 


\section{Introduction}

The focus of majority of the studies carried out on mobile learning so far has been on the context. In this respect, it is seen that most studies have been conducted on subjects like design of mobile learning (Boyle and Ravenscroft, 2012) educational material related to the learner's location, associating in-class learning with out-ofclass learning, and relationship between learners, technologies, and society. One of new trends in mobile learning is the subject of seamless learning. Seamless learning was defined as a continuity of the learning experience across contexts (Chan et al., 2006; Chen et al., 2007; Marinagi et al., 2013; Wu et al., 2013; Virtanen et al., 2017). Seamless learning is not just related to technology. Technologies, activities or resources constitute the most important elements of seamless learning. The technology used in seamless learning is referred to as a learning hub or a technological interface between learners and learning environments (Looi et al., 2009; Bentley et al., 2010). Seamless learning is an aspiration that aims to remove the seams which hinder the permanency of learning. Seamless learning may be intentional or unintentional. For example, a learning activity can start in a classroom and continue at home as homework, or an unintentional discussion among students in a forum on the Internet can lead a deep understanding of the topic learned in the classroom (Sharples, 2015). In seamless learning, learners are not expected to be in a constant process of learning. In seamless learning, the goal is to support and empower learners in terms of learning when they meet a stimulus in any place or at any time (Wong and Looi, 2011). In one review study, it is pointed out that mobile seamless learning has 10 salient features: Encompassing formal and informal learning; Encompassing personalized and social learning; Across time; Across locations; Ubiquitous knowledge access; Encompassing physical and digital worlds; Combined use of multiple device types; Seamless switching between multiple learning tasks; Knowledge synthesis; Encompassing multiple pedagogical or learning activity models (Wong and Looi, 2011).

It could be stated that ubiquitous learning and augmented learning, two terms used in related literature, could be said to be similar to the term of seamless learning. Ubiquitous learning was defined as a learning environment where students can receive instructions, notifications and recommendations anywhere and anytime using ubiquitous mobile technology (Hwang et al., 2008; Virtanen et al., 2017). On the other hand, seamless learning could be said to be a more comprehensive concept. Formal education given at schools, daily experiences out of school or mobile learning environments could all be regarded as part of seamless learning.

When the related literature is examined, it is seen that the importance of seamless learning is gradually increasing. A search in the database of Scopus using (ABS ( "seamless learning") OR ABS ( "ubiquitous learning") OR ABS ("augmented learning" ) ) revealed the results presented in Figure 1 regarding the number of related studies by year.

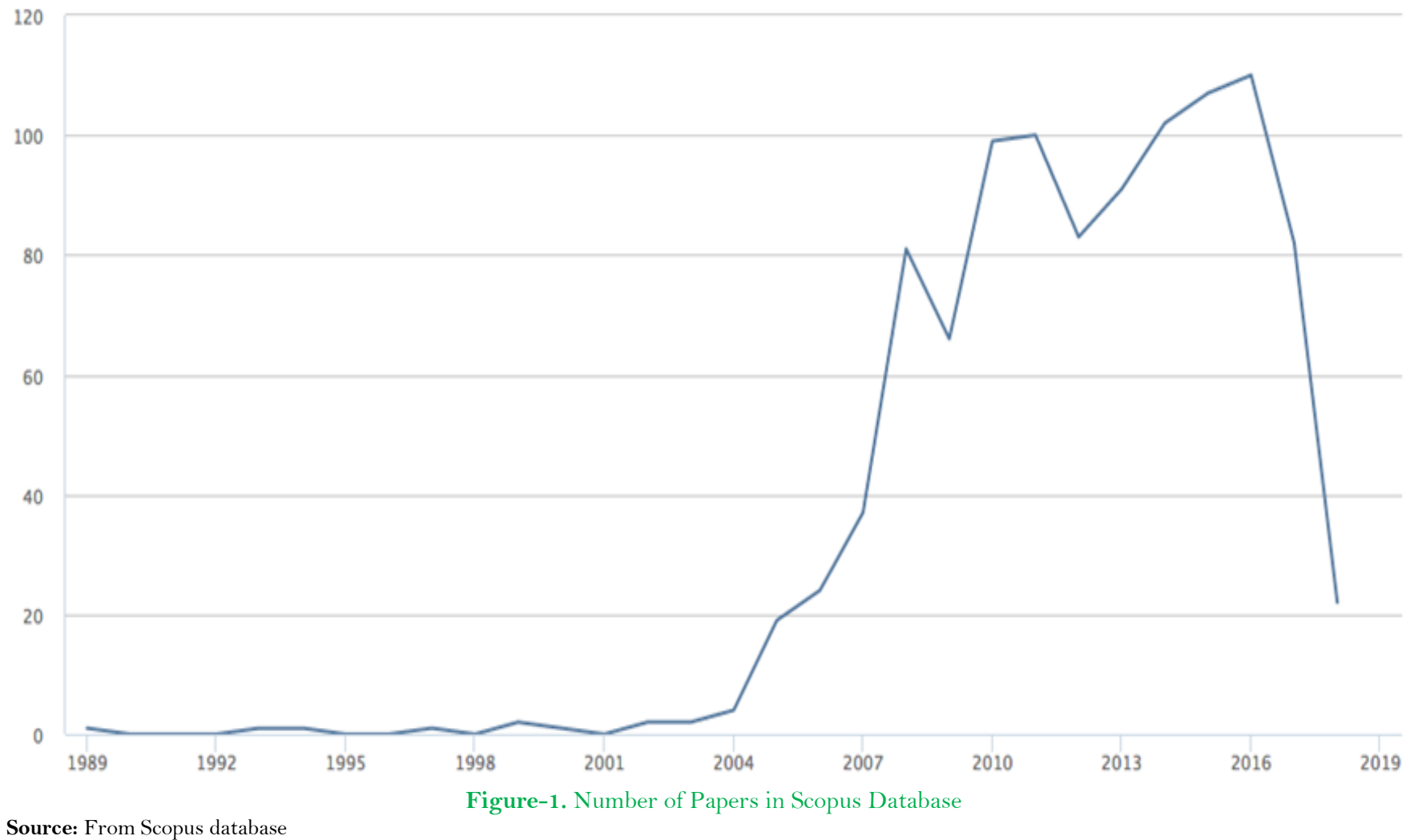

Source: From Scopus database

(https://www.scopus.com/search/form.uri?display=basic)

As can be seen in Figure 1, there has been a gradual increase in the number of studies conducted on seamless learning. With the spread of smart phones and tablet computers especially from the year 2004 on, the applicability and importance of seamless learning has increased more, and a large number of related studies have been conducted. When the related literature is examined, it is seen that there is a need for an up-to-date study reviewing the related literature. Such an up-to-date review study is thought to help researchers see the current trends related to this subject. In this respect, the purpose of the present study was to examine the studies on seamless learning in Scopus database in terms of certain variables.

\section{Related Literature}

In literature, there were two review studies on the concept of seamless learning. This concept is not limited to mobile technologies, and ubiquitous technologies are of great significance for seamless learning. Accordingly, in related literature, the review studies on mobile and ubiquitous learning were examined as well. Therefore, the 
review studies conducted on these concepts are fairly important to help understand the concepts on the whole (Crompton and Burke, 2018).

In one related review study, Sad et al. (2016) conducted a review of 39 seamless learning papers. The researchers found that of all the 39 studies, 14 of them were carried out in Singapore, 6 of them in USA and five of them in Hong Kong. Among all the studies, 33\% of them were carried out with k12 students and $21 \%$ of them with university students. In addition, it was revealed that of all the studies, 14 of them were carried out for the purpose of environment development; that 11 of them were carried out to review the related literature; and that seven of them were conducted using the experimental research design. Wong and Looi (2011) examined 54 papers about seamless learning. They found that among the studies, 32 of them were related to development of environments and that 11 of them were related to conceptual, pedagogical designs.

Hwang and $\mathrm{Wu}(2014)$ reviewed 214 papers about mobile and ubiquitous learning published in SSCI indexed journals. They found that among these 214 studies, 83 of them examined the variable of academic achievement and that 44 of them examined the variable of motivation. Also, according to the researchers, most of these studies revealed that mobile and ubiquitous learning had positive influence on academic achievement and motivation. Virtanen et al. (2017) in their review study, examined a total of seven papers, five of which were carried out on ubiquitous learning in Taiwan and two of which were in Japan. They found that questionnaires, surveys, assessments or knowledge tests $(n=4)$, semi-structured, group interviews $(n=4)$ and textual data $(n=3)$ were used as data collection tools. They also stated that review studies examined the variables of effectiveness, costeffectiveness, satisfaction and usefulness, and they reported that ubiquitous learning increased learning effectiveness. Hwang and Tsai (2011) conducted a review study on mobile and ubiquitous learning and reached 154 articles. They found that of all 154 studies, 51 of them were carried out in Taiwan, 16 of them in England and 12 of them in USA. They also found that the participants in the studies were university students (n=59), elementary school students (41) and high school students (17). Wu et al. (2012) reviewed 164 mobile learning studies with meta-analysis technique. They found that most of the studies were on effectiveness and environment development. In addition, the researchers reported that surveys and experimental methods were the most frequent research methods and that mobile learning had positive influence on students' achievement. Jagušt et al. (2018) examined a total of 43 experimental studies carried out on technology use out of school at k12 level. They found that of all these 43 studies, 33 of them examined the variables of attitude, motivation and engagement and that in 25 studies, quasi-experiments with pre-tests and post-tests were used. Cheung and Hew (2009) conducted a review of research methodologies used in mobile learning and reviewed 44 articles. They found that the most frequent research methods were descriptive research (65.9\%), experimental (20.4\%), mixed method (6,8\%), design-based (2.3\%) and single subject (2.3\%), respectively. They also found that the most frequent data collection methods included $31.4 \%$ questionnaire, $22.5 \%$ test or quiz items, $20.6 \%$ content analysis, $18.6 \%$ interview or focus group, and $6.9 \%$ observation, respectively. In addition, regarding the research topics, the researchers reported that $49.1 \%$ of them were about learners' attitudes, $26.3 \%$ about usage profile, and $17.5 \%$ about learning outcome. Hung and Zhang (2012) examined mobile learning trends between 2003 and 2008 with the analysis of 119 articles. They found that of all the studies, $27.7 \%$ of them were carried out in Taiwan, $15.1 \%$ in USA, 9.2\% in South Korea and 7.6\% in England. The researchers also found that among 119 studies, 50 of them focused on effectiveness, 25 of them on case study, 25 of them on strategies and frameworks, and 19 of them on acceptance and issues.

\section{Methodology}

In this study, content analysis was conducted on articles found in the database of Scopus regarding the concept of "seamless learning". Content analysis is "a research method for the subjective interpretation of the content of text data through the systematic classification process of coding and identifying themes or patterns" (Hsieh and Shannon, 2005). This type of study is considered to be effective in guiding future studies by summarizing a large volume of literature (Petticrew and Roberts, 2006) and in this respect, the researchers made use of content analysis (Wilson, 2011). As a research method, it represents a systematic and objective tool for describing and quantifying phenomena (Schreier, 2012).

The related literature was reviewed considering the following criteria for the articles: being written in English, being published in a reviewed journal and being published in the last 10 years (2009-2018). For the purpose of reaching the related articles, Scopus database was searched. Scopus is the largest abstract and citation database for peer-reviewed literature (Buyukkol et al., 2018) and it lists scientific journals, books and conference proceedings (Scopus, 2018). For the search, 'seamless learning' and 'seamless teaching' were used in the 'article title', and various concepts likely to be covered by the concept of 'seamless learning' such as distance education and education technology were used in the 'abstract'. In this way, the purpose was to reach the articles appropriate to the research purpose. The search done on Scopus was as follows:

(TITLE-ABS-KEY ( "seamless learning" ) OR TITLE-ABS-KEY ( "seamless teaching" ) ) AND

DOCTYPE ( ar OR re) AND (LIMIT-TO ( SUBJAREA, "SOCI") OR LIMIT-TO ( SUBJAREA,

"COMP" ) OR LIMIT-TO ( SUBJAREA, "ENGI" )) AND ( LIMIT-TO ( LANGUAGE, "English" ))

As a result of this search, 90 articles were listed. Of all these articles, 73 of them were full-text, and seventeen articles were excluded from the scope of the present study as they were not reached as full-text articles. As a result, a total of 73 articles were examined in relation to the key words. Consequently, 15 articles which were not considered to be directly related to the research purpose of the present study were excluded. The overall research flow is presented in Figure 2. 


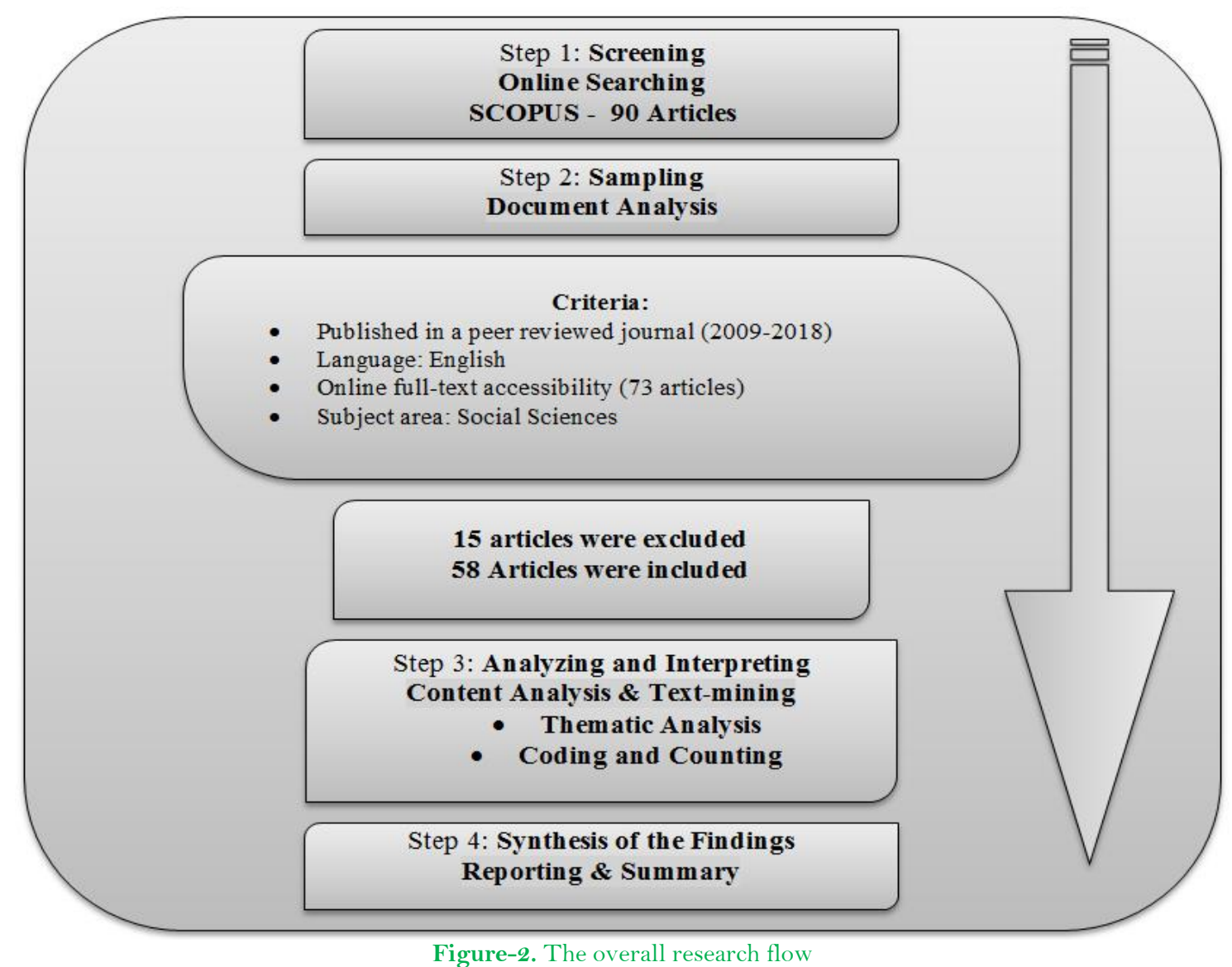

As a result, in the present study, content analysis was conducted on a total of 58 full-text articles to find answers to the research questions, and the related articles were examined in terms of certain variables. In the study, percentages and frequencies were used to examine the descriptive statistics regarding the variables, participants and data collection tools in the articles. Next, these statistics were interpreted by comparing them with the results of other similar studies in related literature.

\subsection{Reliability}

Based on the previously defined criteria, a table was prepared for the articles reached via the search. The articles were analysed by two researchers individually, and they noted the results down in their own tables. Next, the tables prepared by the researchers were compared to identify the differences, and the related articles were examined again. Inter-rater reliability of the second-round coding was found to be $\kappa=.895$. Altman (1990) suggests that the extent of agreement for Cohen's kappa can be qualified as very good (0.81 to 1.00). Therefore, the reliability of the first and second raters can be regarded as very good. When consensus was reached on all the findings, the content analysis was finalized.

\section{Findings and Discussions}

This section deals with trends in research methods and model/designs, participants, data collection tools, variables, and patterns in keywords in Seamless Learning research. Figure 3 presents the distribution of the 94 articles by year.

\section{Number of Seamless Learning Publications by Year}

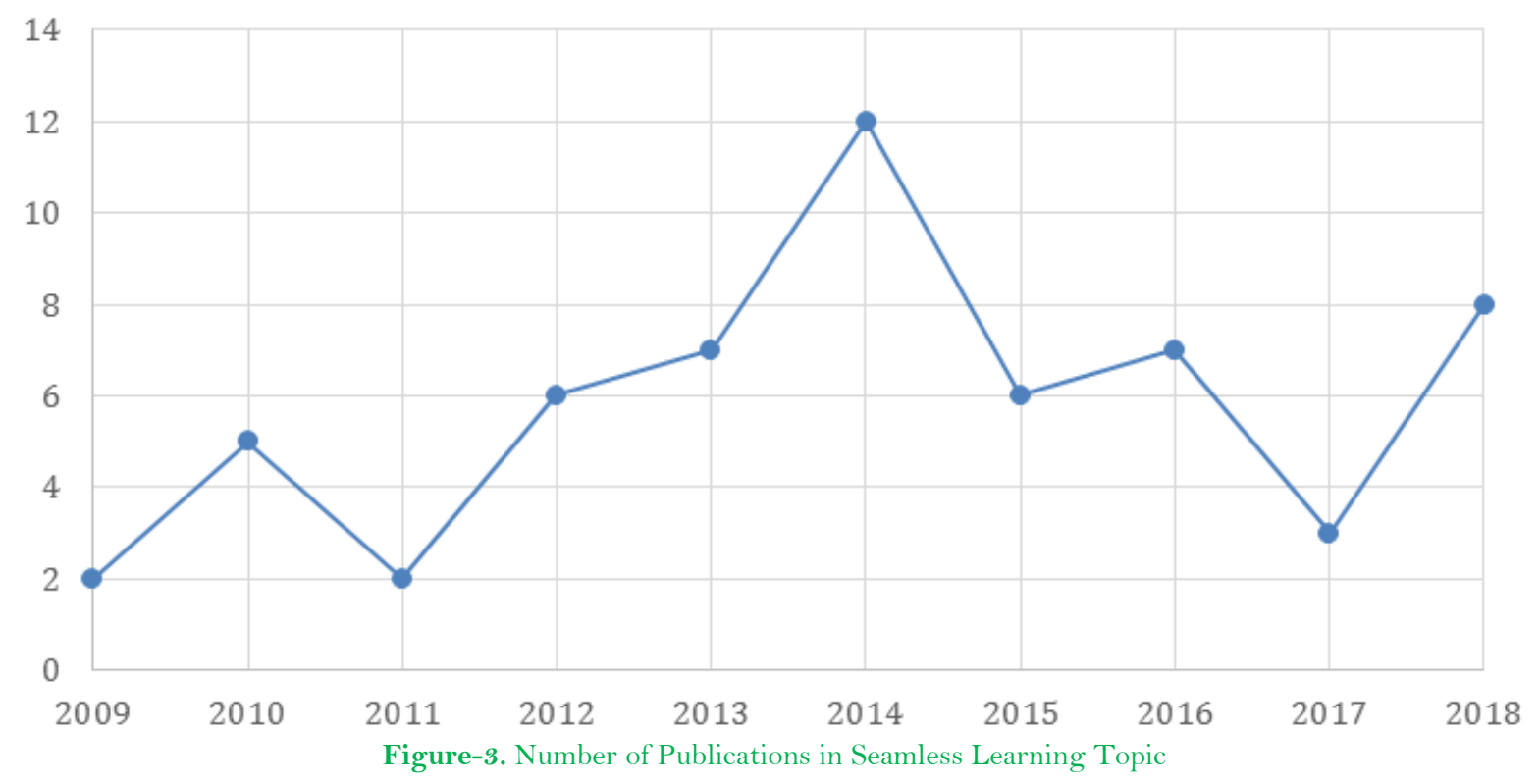


According to the graph, the highest number of articles belonged to 2014, and there were only two articles in 2009 and 2011. During the time between 2009 and 2018, it could be stated that the number of articles tended to increase. Also, in the study, the journals where the articles were published were examined. The results can be seen in Figure 4.

\section{Number of Publications}

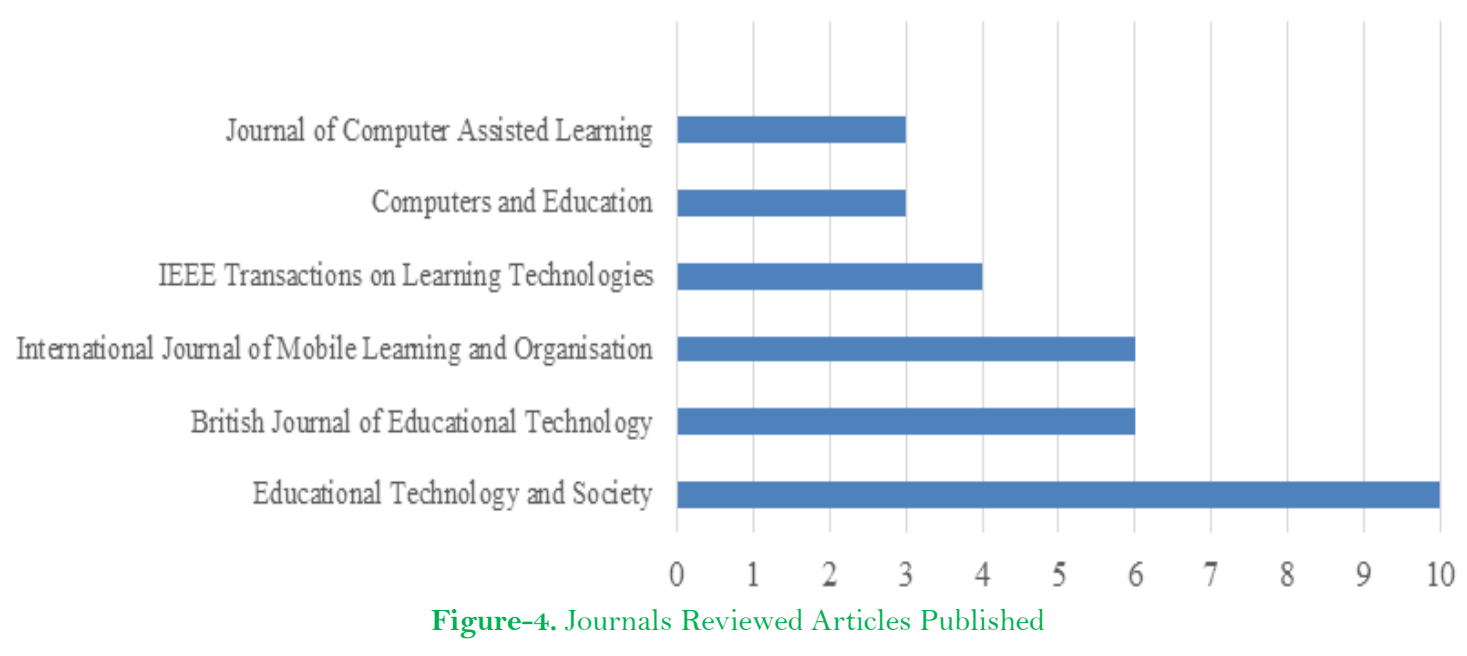

Accordingly, the first five journals where the articles were mostly published included Educational Technology and Society, International Journal of Mobile Learning and Organization, IEEE Transactions on Learning Technologies, Computers \& Education and Journal of Computer Assisted Learning. This was an expected result as these journals were the leading ones in the field of educational technology.

Figure 5. Shows the distribution of the countries where the studies were conducted.

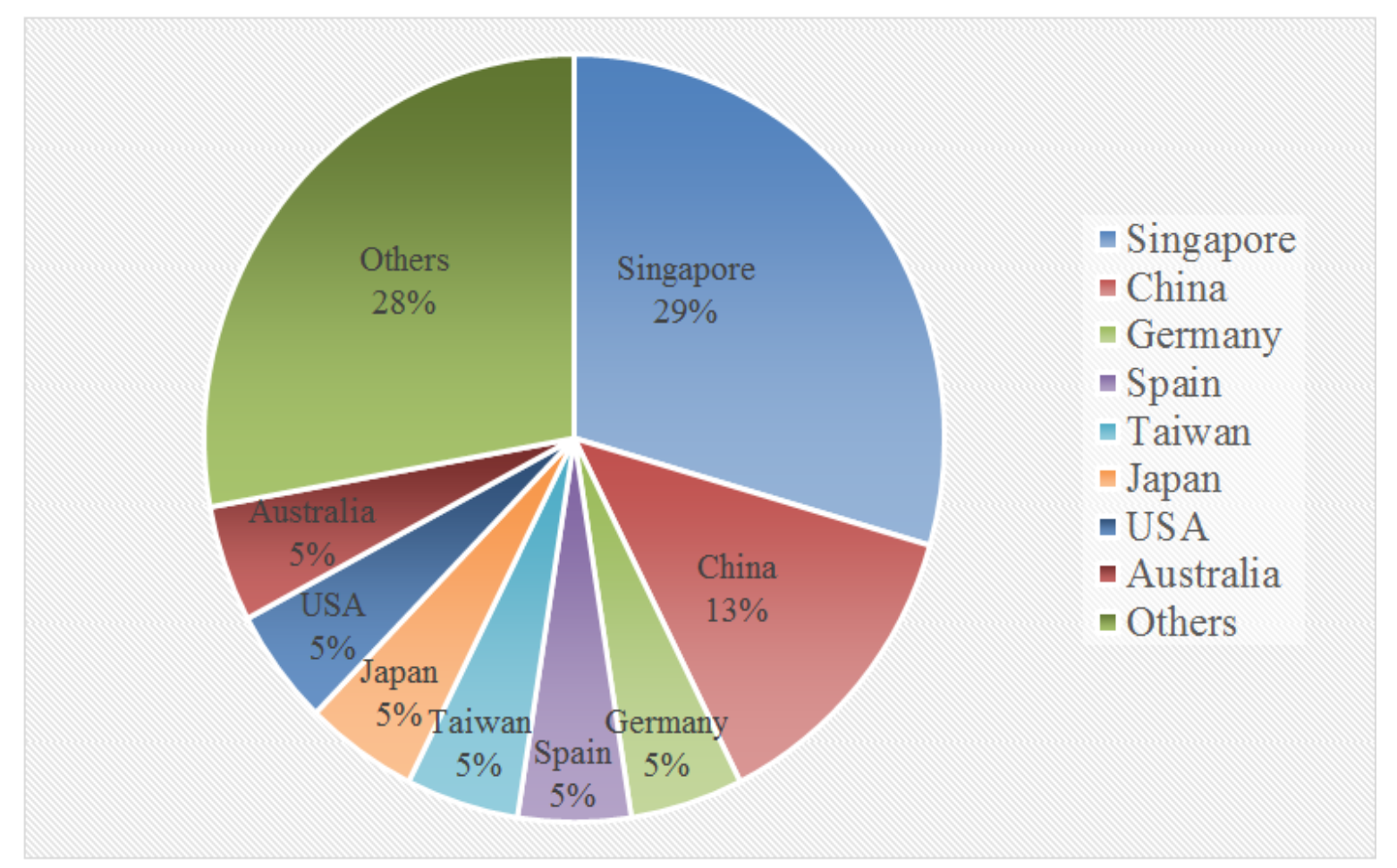

Figure-2. Countries where the studies were conducted

When Figure 5 is examined, it is seen that Singapore was well ahead of all the other countries where the related studies were conducted. Singapore was followed by China. Germany, Spain, Taiwan, Japan, USA and Australia had the same ratio. The countries which formed the group of 'others' were those where only one or two studies were conducted. Among these countries were UK, Netherlands and Sweden. The fact that Singapore and China were the leading countries is consistent with the result reported by Sad et al. (2016). In addition, the findings obtained in other studies in related literature (Hwang and Tsai, 2011; Hung and Zhang, 2012; Virtanen et al., 2017) are similar to the results obtained in relation to the list of countries. When compared with the results reported in related literature, it could be stated that Singapore was a leading country in terms of seamless learning, while Taiwan was a leading country in terms of mobile and ubiquitous learning. In general, Far East countries could be said to be more interested in such subjects. The reason for this is thought to be the fact that there is a higher level of need for distance education in these countries due to their dense population.

\subsection{Most Cited 10 Studies}

The studies included in the present study were also examined with respect to the number of references, and the results obtained in relation to the first 10 studies are presented in Table 1. 
Table-1. List of Authors with the Highest Number of Citations and the Main Focus of the Study

\begin{tabular}{|c|c|c|c|c|c|c|}
\hline Publication Name & Authors & Year & Journal & $\begin{array}{l}\text { Cited } \\
\text { by }\end{array}$ & $\begin{array}{l}\text { Research } \\
\text { Methods }\end{array}$ & Main Focus of The Study \\
\hline \begin{tabular}{lrr|} 
Leveraging & mobile \\
technology & for \\
sustainable & seamless \\
learning: & A & research \\
agenda & & \\
\end{tabular} & \begin{tabular}{|lll} 
Looi & et & al. \\
$(2010)$ & &
\end{tabular} & $(2010)$ & $\begin{array}{l}\text { British Journal } \\
\text { of Educational } \\
\text { Technology }\end{array}$ & 231 & $\begin{array}{l}\text { Literature } \\
\text { review }\end{array}$ & $\begin{array}{l}\text { This paper reviews the } \\
\text { potential of mobile learning } \\
\text { research for designing } \\
\text { seamless } \\
\text { environments that can } \\
\text { bridge both formal and } \\
\text { informal learning. }\end{array}$ \\
\hline $\begin{array}{l}\text { What seams do we } \\
\text { remove in mobile-assisted } \\
\text { seamless learning? A } \\
\text { critical review of the } \\
\text { literature }\end{array}$ & $\begin{array}{l}\text { Wong and } \\
\text { Looi (2011) }\end{array}$ & $(2011)$ & $\begin{array}{l}\text { Computers and } \\
\text { Education }\end{array}$ & 222 & $\begin{array}{l}\text { Systematic } \\
\text { review }\end{array}$ & $\begin{array}{l}\text { This paper investigates the } \\
\text { meaning of seamless } \\
\text { learning and the potential } \\
\text { ways to put it in practice. }\end{array}$ \\
\hline $\begin{array}{l}\text { A learner-centric view of } \\
\text { mobile seamless learning }\end{array}$ & Wong (2012) & $(2012)$ & $\begin{array}{l}\text { British Journal } \\
\text { of Educational } \\
\text { Technology }\end{array}$ & 98 & $\begin{array}{l}\text { Literature } \\
\text { review }\end{array}$ & $\begin{array}{l}\text { This paper attempts to } \\
\text { provide a more holistic } \\
\text { picture of mobile seamless } \\
\text { learning. }\end{array}$ \\
\hline $\begin{array}{l}\text { Students' personal and } \\
\text { social meaning making in } \\
\text { a Chinese idiom mobile } \\
\text { learning environment }\end{array}$ & $\begin{array}{|lll|}\text { Wong et al. } \\
(2010)\end{array}$ & $(2010)$ & $\begin{array}{l}\text { Educational } \\
\text { Technology } \\
\text { and Society }\end{array}$ & 90 & $\begin{array}{l}\text { Design-based } \\
\text { research }\end{array}$ & $\begin{array}{l}\text { This paper presents a } \\
\text { design research study in } \\
\text { Mobile Assisted Language } \\
\text { Learning that emphasizes } \\
\text { learner created content and } \\
\text { contextualized meaning } \\
\text { making. }\end{array}$ \\
\hline $\begin{array}{l}\text { "Bring Your Own Device } \\
\text { (BYOD)" for seamless } \\
\text { science inquiry in a } \\
\text { primary school }\end{array}$ & Song (2014) & $(2014)$ & $\begin{array}{l}\text { Computers and } \\
\text { Education }\end{array}$ & 78 & $\begin{array}{l}\text { MIXed/ } \\
\text { Triangulation }\end{array}$ & $\begin{array}{l}\text { This paper reports a one- } \\
\text { year study on the project of } \\
\text { "Bring Your Own Device } \\
\text { for seamless science } \\
\text { inquiry" in a primary school } \\
\text { in Hong Kong }\end{array}$ \\
\hline $\begin{array}{l}\text { Schools going mobile: A } \\
\text { study of the adoption of } \\
\text { mobiler handheld } \\
\text { technologies in western } \\
\begin{array}{l}\text { Australian independent } \\
\text { schools }\end{array}\end{array}$ & \begin{tabular}{|l|} 
Pegrum et al. \\
$(2013)$
\end{tabular} & $(2013)$ & \begin{tabular}{|l|} 
Australasian \\
Journal of \\
Educational \\
Technology
\end{tabular} & 76 & Case Study & $\begin{array}{l}\text { This paper reports on the } \\
\text { adoption of mobile } \\
\text { handheld technologies in } \\
\text { ten Western Australian } \\
\text { independent schools. }\end{array}$ \\
\hline $\begin{array}{l}\text { Vocabulary learning by } \\
\text { mobile-assisted authentic } \\
\text { content creation and } \\
\text { social meaning-making: } \\
\text { Two case studies }\end{array}$ & $\begin{array}{l}\text { Wong and } \\
\text { Looi (2010) }\end{array}$ & $(2010)$ & $\begin{array}{l}\text { Journal of } \\
\text { Computer } \\
\text { Assisted } \\
\text { Learning }\end{array}$ & 75 & Case Study & $\begin{array}{l}\text { This paper shows the } \\
\text { potential of transforming } \\
\text { language learning into an } \\
\text { authentic seamless learning } \\
\text { experience. }\end{array}$ \\
\hline $\begin{array}{l}\text { Applications, impacts and } \\
\text { trends of mobile } \\
\text { technology-enhanced } \\
\text { learning: A review of } \\
\text { 2008-2012 publications in } \\
\text { selected SSCI journals }\end{array}$ & $\begin{array}{l}\text { Hwang and } \\
\mathrm{Wu}(2 \mathrm{O} 14)\end{array}$ & $(2014)$ & $\begin{array}{l}\text { International } \\
\text { Journal of } \\
\text { Mobile } \\
\text { Learning and } \\
\text { Organisation }\end{array}$ & 74 & $\begin{array}{l}\text { Systematic } \\
\text { review }\end{array}$ & $\begin{array}{l}\text { This paper investigates the } \\
\text { applications and impacts of } \\
\text { mobile technology- } \\
\text { enhanced learning by } \\
\text { review of literature. }\end{array}$ \\
\hline $\begin{array}{lrr}\text { How artefacts } & \text { mediate } \\
\text { small-group } & \text { co-creation } \\
\text { activities in a } & \text { mobile- } \\
\text { assisted } & & \text { seamless } \\
\text { language } & & \text { learning } \\
\text { environment? } & & \end{array}$ & $\begin{array}{l}\text { Wong et al. } \\
(2012)\end{array}$ & $(2012)$ & $\begin{array}{l}\text { Journal of } \\
\text { Computer } \\
\text { Assisted } \\
\text { Learning }\end{array}$ & 38 & Case Study & $\begin{array}{l}\text { This paper presents an } \\
\text { intervention study in } \\
\text { 'Move, Idioms!', a mobile- } \\
\text { assisted Chinese language } \\
\text { learning approach that } \\
\text { emphasizes contextualized } \\
\text { learner content creation } \\
\text { and meaning making with } \\
\text { their daily encounters. }\end{array}$ \\
\hline $\begin{array}{lrr}\text { Fostering } & \text { personalized } \\
\text { learning } & \text { in } \quad \text { science } \\
\text { inquiry } & \text { supported by } \\
\text { mobile technologies } & \end{array}$ & $\begin{array}{|lll|}\begin{array}{l}\text { Song } \\
(2012)\end{array} & & \end{array}$ & $(2012)$ & $\begin{array}{l}\text { Educational } \\
\text { Technology } \\
\text { Research and } \\
\text { Development }\end{array}$ & 37 & Case Study & $\begin{array}{l}\text { This paper presents a } \\
\text { mobile technology-assisted } \\
\text { seamless learning process } \\
\text { design where students were } \\
\text { facilitated to develop their } \\
\text { personalized and diversified } \\
\text { understanding in a primary } \\
\text { school's science topic of the } \\
\text { life cycles of various living } \\
\text { things. }\end{array}$ \\
\hline
\end{tabular}

When Table 1 is examined, it is seen that nearly half of the articles cited most were literature reviews conducted with the Conceptual/Descriptive methods. Also, the first three studies cited most were review studies. Based on this situation, it could be stated that the researchers benefitted more from the review studies which summarized the studies in related literature and which presented these studies in a systematic manner. Researchers who want to carry out studies on the related research topic can save time by getting informed more about the related literature by making use of such review studies. Especially in the first two studies, the number of citations was higher than 200. Of all the most cited studies, four of them were carried out using the case study method, and one was conducted using the design-based research method. In the most cited study in Table 1, the 
focus was on how seamless learning can combine formal and informal learning, and a related research agenda was put forward (Looi et al., 2010). The second most cited study was related to the meaning of seamless learning and the potential ways to put it in practice (Wong and Looi, 2011). When the authors of the most cited studies were examined, it was seen that seven out of the 10 studies were carried out by a group of researchers from Singapore. Lung-Hsiang Wong, one of the authors, was found in seven most cited studies. Moreover, Lung-Hsiang Wong was the only author of the third most cited study.

\subsection{Keyword Analysis}

Figure 6 depicts the major topics covered in the selected articles published between 2009 and 2018.

Figure 6 presents the relationships regarding the keywords used in the studies. When the frequencies of the keywords in the articles were examined, it was seen that concepts such as "learning", "student", "seamless learning environment" were prominent. This graph could be said to be explanatory enough to reveal the relationships between the keywords. In review studies conducted on seamless learning, mobile and ubiquitous learning in related literature, it was seen that they did not include any keyword analysis. However, in general, it could be stated that keywords such as learning, student, teacher, practice, mobile technology and mobile device are among the basic concepts in this field. Different from that, it is seen in the present study that the concept of seamless learning environment was prominent.

\& vosviewer

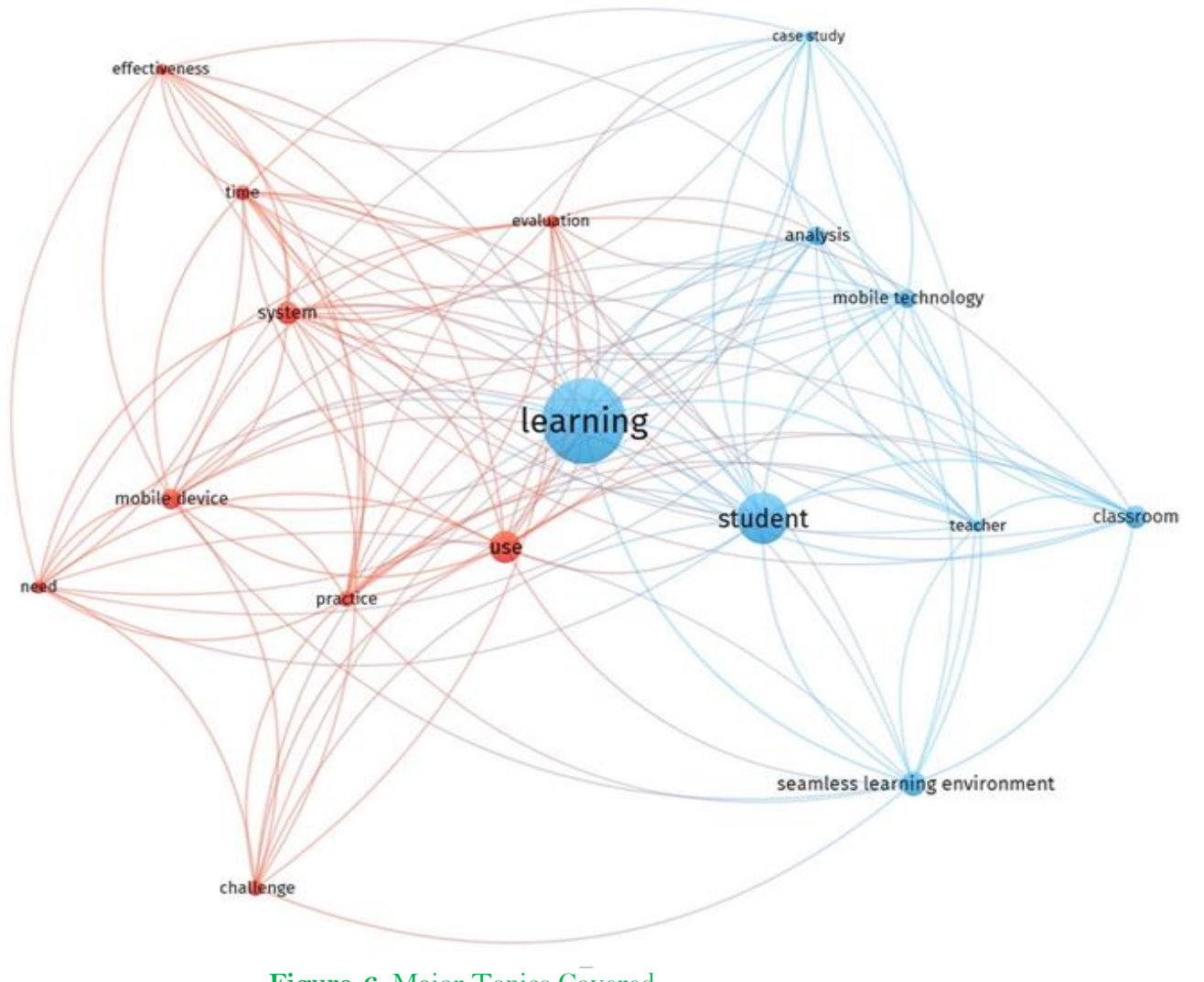

Figure-6. Major Topics Covered

\subsection{Participants}

Table 2 presents the frequencies and percentages regarding the participants in the articles examined within the scope of the present study.

Table-2. Participants

\begin{tabular}{l|l|l|l}
\hline Participants & Frequency & Percentage & Sample Size \\
\hline K-12 Students & 18 & 50 & $3-614$ \\
\hline Undergraduate students & 14 & 38,9 & $4-241$ \\
\hline K-12 Teachers & 2 & 5,5 & $2-195$ \\
\hline Administrators & 1 & 2,8 & 3 \\
\hline Adults & 1 & 2,8 & $1-60$ \\
* One study may employ more than one target group
\end{tabular}

When the data presented in Table 2 are examined, it is seen that $\mathrm{K}-12$ students $(\mathrm{N}=18)$ and undergraduate students $(\mathrm{N}=14)$ were in the first two places and that these groups constituted approximately $89 \%$ of all the participants. When the sample sizes were examined, it was seen that there were minimum three and maximum 614 learners as K-12 students and that the number of learners ranged between 4 and 241 for undergraduate students. The fact that K-12 students and undergraduate students were favoured more as participants is parallel to the findings of other related studies in literature (Hwang and Tsai, 2011; Sad et al., 2016).

\subsection{Data Collection Tools}

Table 3 presents frequencies and percentages regarding the data collection tools used in the articles examined within the scope of the study. 


\begin{tabular}{l|l|l}
\hline \multicolumn{2}{c}{ Table-1. Data Collection Tools } & Percentage \\
\hline Data Collection Tools & Frequency & 19,6 \\
\hline Interview & 19 & 17,5 \\
\hline Academic achievement tests & 17 & 15,4 \\
\hline Questionnaire & 15 & 11,3 \\
\hline Document analysis & 11 & 8,2 \\
\hline Observation & 8 & 7,2 \\
\hline Video recordings & 7 & 5,1 \\
\hline Others & 5 & 5,1 \\
\hline Scale & 5 & 4,1 \\
\hline Focus group & 4 & 3,1 \\
\hline Field notes & 3 & 2,1 \\
\hline Discussion post & 2 & 1,0 \\
\hline Log & 1 &
\end{tabular}

According to Table 3, as the most popular data collection tools, interview (19,6\%), academic achievement $(17,5 \%)$, questionnaire $(15,4 \%)$ and document analysis $(11,3 \%)$ were the most frequent ones used in these studies. The fact that interview, academic achievement tests and questionnaire were the most common data collection tools is also supported by other research results in related literature (Cheung and Hew, 2009; Hwang and Tsai, 2011; Virtanen et al., 2017; Jagušt et al., 2018).

\subsection{Variables/Research Interests}

The articles were categorized with respect to the dependent variables. Table 4 presents the related frequencies and percentages. It was seen that there were more than one dependent variable in one study, while there was none in some of the studies. Especially in qualitative and review studies, no dependent variable was used.

\begin{tabular}{l|l|l}
\multicolumn{3}{c}{ Table-4. Variables / Research Interests } \\
\hline Dependent Variables & $\mathbf{f}$ & $\mathbf{\%}$ \\
\hline Academic-performance & 11 & 31,4 \\
\hline Perception & 8 & 22,9 \\
\hline Effectiveness & 5 & 14,2 \\
\hline Motivation & 4 & 11,4 \\
\hline Usability & 3 & 8,6 \\
\hline Self-efficacy & 2 & 5,7 \\
\hline Others & 2 & 5,7 \\
\hline
\end{tabular}

According to Table 4, the most frequent dependent variable was "academic performance" (31,4 \%) used in 11 studies. This variable was followed by perception (14,2\%) in 8 studies, "effectiveness" $(14,2 \%)$ in 5 studies, "motivation" $(11,4 \%)$ in 4 studies and "usability" $(8,6 \%)$ in 3 studies. It was seen that the most frequent dependent variables used in the articles were academic performance, perception and effectiveness, and they constituted almost half of all the variables. This result is similar to the findings of other studies carried out by (Cheung and Hew, 2009; Hung and Zhang, 2012; Wu et al., 2012; Hwang and Wu, 2014; Virtanen et al., 2017).

\subsection{Research Method and Design}

An analysis of the findings about Research Method and Design was presented in Table 5.

The analysis revealed that researchers mostly preferred Conceptual/Descriptive methods (36\%), while literature reviews $(n=9)$ and reflection paper $(n=6)$ were the most frequent ones used in Conceptual/Descriptive methods. Qualitative methods (\%21) were the second most preferred research paradigm, and among these studies, case study $(\mathrm{n}=12)$ was the most common in these studies. Quantitative method studies scored the next highest $(17 \%)$, and experimental studies $(n=6)$ and survey $(n=3)$ were the most frequent ones used in Quantitative methods. Mixed methods (14\%) and practice-based research methods (14\%) were the fourth most preferred research paradigms. Explanatory sequential $(n=3)$ and transformative $(n=3)$ were the leading research models in mixed methods. Design-based research $(n=8)$ was the only research model preferred in practice-based methods. In the sampled publications, none of the studies used data mining or analytical methods. The most popular research methods and models were different in different review studies. In this study, the most common ones were Conceptual/Descriptive methods. On the other hand, in some other studies, quantitative methods (Hung and Zhang, 2012; Wu et al., 2012; Jagušt et al., 2018) were more common, and still in some other studies, the qualitative methods (Cheung and Hew, 2009) were favoured more. Similar to the related finding obtained in the present study, in two review studies carried out by Sad et al. (2016) and Wong and Looi (2011) Conceptual/Descriptive methods were used more. Thus, it could be stated that in recent studies, Conceptual/Descriptive methods have become more popular. 
Table-5. Frequencies of Methods and Models/Designs

\begin{tabular}{|c|c|c|c|c|c|c|}
\hline Method & $\mathbf{f}$ & $\%$ & Model/Design & $\mathbf{f}$ & $\%$ CUM & \%TOTAI \\
\hline \multirow{5}{*}{ Quantative } & \multirow{5}{*}{9} & \multirow{5}{*}{17} & Survey & 3 & 33 & 5 \\
\hline & & & Experimental & 6 & 67 & 10 \\
\hline & & & Causal Comparative & $\mathbf{0}$ & $\mathbf{0}$ & $\mathbf{0}$ \\
\hline & & & Correlational & o & $\mathbf{0}$ & o \\
\hline & & & Meta-analysis & $\mathbf{0}$ & $\mathbf{0}$ & $\mathbf{0}$ \\
\hline \multirow{9}{*}{ Qualitative } & \multirow{9}{*}{12} & \multirow{9}{*}{21} & Case Study & 12 & 100 & ] 21 \\
\hline & & & Content Analysis & $\mathbf{0}$ & $\mathbf{o}$ & $\mathbf{o}$ \\
\hline & & & Etnography & o & $\mathbf{0}$ & $\mathbf{o}$ \\
\hline & & & Descriptive & $\mathbf{o}$ & o & $\mathbf{o}$ \\
\hline & & & Phenomenology & 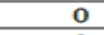 & $\mathbf{0}$ & $\mathbf{0}$ \\
\hline & & & Grounded Theory & $\mathbf{o}$ & o & $\mathbf{0}$ \\
\hline & & & Meta-synthesis & o & $\mathbf{0}$ & $\mathbf{0}$ \\
\hline & & & Historical & 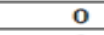 & $\mathbf{0}$ & $\mathbf{0}$ \\
\hline & & & Heuristic & o & $\mathbf{0}$ & $\mathbf{0}$ \\
\hline \multirow{6}{*}{ Mixed } & \multirow{6}{*}{8} & \multirow{6}{*}{14} & Explanatory sequential & 3 & 37 & 5 \\
\hline & & & Embedded & 1 & 13 & 2 \\
\hline & & & Convergent Parallel & 1 & 13 & 2 \\
\hline & & & Exploratory Sequential & $\mathbf{o}$ & $\mathbf{o}$ & $\mathbf{o}$ \\
\hline & & & Multiphase & o & o & $\mathbf{o}$ \\
\hline & & & Transformative & 3 & 37 & 5 \\
\hline \multirow{9}{*}{$\begin{array}{c}\text { Conceptual/Descriptive } \\
\text { /Other }\end{array}$} & \multirow{9}{*}{21} & \multirow{9}{*}{36} & Opinion Paper & 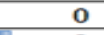 & $\mathbf{0}$ & 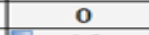 \\
\hline & & & Literature Review & 9 & 56 & 16 \\
\hline & & & Report & 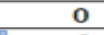 & $\mathbf{0}$ & $\mathbf{0}$ \\
\hline & & & Reflection Paper & 6 & 38 & 10 \\
\hline & & & Comparative & $\mathbf{0}$ & $\mathbf{0}$ & $\mathbf{0}$ \\
\hline & & & Technical Paper & 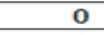 & $\mathbf{o}$ & $\mathbf{0}$ \\
\hline & & & Position Paper & 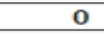 & $\mathbf{0}$ & $\mathbf{0}$ \\
\hline & & & Field Notes & 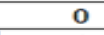 & $\mathbf{0}$ & $\mathbf{o}$ \\
\hline & & & Systematic Review & 1 & 6 & 2 \\
\hline \multirow{2}{*}{ Practice Based } & \multirow{2}{*}{8} & \multirow[b]{2}{*}{14} & Design Based Research & 8 & 100 & 14 \\
\hline & & & Action Research & $\mathbf{0}$ & o & $\mathbf{o}$ \\
\hline \multirow{6}{*}{ Data Mining and Analysis } & \multirow{6}{*}{$\mathbf{o}$} & \multirow{6}{*}{ o } & Learning Analytics & 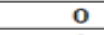 & $\mathbf{0}$ & $\mathbf{0}$ \\
\hline & & & Social Network Analysis & $\mathbf{o}$ & $\mathbf{0}$ & $\mathbf{0}$ \\
\hline & & & Text Mining & $\mathbf{0}$ & $\mathbf{0}$ & $\mathbf{0}$ \\
\hline & & & Log Analysis & 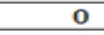 & $\mathbf{0}$ & $\mathbf{0}$ \\
\hline & & & Internet and Traffic Ranks & $\mathbf{o}$ & $\mathbf{0}$ & $\mathbf{0}$ \\
\hline & & & Sentiment Analysis & o & $\mathbf{o}$ & $\mathbf{o}$ \\
\hline
\end{tabular}

\section{Conclusion and Future Research Directions}

This study explored 58 publications to identify the trends and patterns regarding the concept of seamless learning. The findings revealed that from 2009 to 2014, an increasing interest was witnessed in seamless learning as well as an apparent positive trend. Although there was a little decrease in the number of studies carried out after 2014, it increased again in 2018 meaning that the number of publications that cover this concept will probably continue to increase.

When the 58 articles were taken into account with respect to their research methods and models, it was seen that Conceptual/Descriptive methods and Qualitative methods were prominent. The Quantitative methods constituted $17 \%$ of all the methods, while Mixed and Practice Based methods each formed $14 \%$. This result was surprising as experimental methods are not much favoured in studies carried out on seamless learning, which is supposed to have practical implementations. The journals where the most cited studies were published were found to include British Journal of Educational Technology, Computers \& Education, Australasian Journal of Educational Technology, Educational Technology and Society and Journal of Computer Assisted Learning. Based on this, it could be stated that the concept of learning spaces can be associated more with the field of educational technology. The studies related to the concept of seamless learning were examined with respect to their being cited. When the first ten studies in the list were examined, it was seen that the most cited 3 studies were carried out with literature review research models found under the category of Conceptual/Descriptive methods. Accordingly, it could be stated that the researchers made use of such studies which summarized the studies in related literature and which presented these studies in a systematic way. The present study, which was designed as content analysis, is thought to be a study which will guide researchers who will study on the concept of seamless learning. As a result of the analysis of the keywords, it was seen that they mostly included learning, student, use, seamless learning environment, system, mobile technology, mobile device, time and practice. Considering the fact that the common point of these concepts was mobile learning, the concept of seamless learning could be said to be interwoven with mobile learning. In the articles examined in the study, it was seen that half of the participants were k-12 students. This could be regarded as an unexpected result because a lot more studies are conducted on online education at universities, which provide students with opportunities to get online certificates and an associate, graduate or postgraduate degree. Therefore, the participants in studies like this could be expected to be mostly university students. When examined in terms of the data collection tools used, interview, academic achievement test and questionnaire were dominant.

As demonstrated by the review of the related literature, there isn't any content analysis conducted on the concept of seamless learning. Therefore, the present study is expected to be a pioneering one. Based on the findings of this research, the following suggestions could be put forward for future studies:

- Researchers who plan to conduct studies on the concept of seamless learning may use dependent variables which were used less frequently in previous studies. In this way, instead of conducting similar studies, maximum variety can be obtained regarding the related concept.

- Several different variables (country, language, article, thesis, etc.) can be compared thanks to content analysis conducted on extensive sampling.

- There is a need for gender studies particularly focusing on the gender imbalance in seamless learning.

- When the articles examined in the present study were taken into account with respect to the methods used, it was seen that mixed methods ranked fourth. However, increasing the number of mixed studies, which make use of advantages of both qualitative and quantitative methods, could allow gathering more in-depth data in the related field. 
- Finally, seamless learning practices may benefit more from online learning environments, and analysis of such practices through data mining and analytical approaches may produce effective and efficient research findings.

\section{References}

Altman, D.G., 1990. Practical statistics for medical research. London: CRC Press.

Bentley, Y., A. Shegunshi and M. Scannell, 2010. Evaluating the impact of distance learning support systems on the learning of MBA students in global context. Electronic Journal of E-Learning, 8(2): 51-62.

Boyle, T. and A. Ravenscroft, 2012. Context and deep learning design. Computers \& Education, 59(4): 1224-1233.Available at: https://doi.org/10.1016/j.compedu.2012.06.007.

Buyukkol, K.E., G. Cetin and E. Yunkul, 2018. A content analysis of studies related to educational technologies in biology education. Journal of Educational Technology and Online Learning, 1(2): 1-15.Available at: http://doi.org/10.31681/jetol.419932.

Chan, T.-W., J. Roschelle, S. Hsi, Kinshuk, M. Sharples, T. Brown, C. Patton, J. Cherniavsky, R. PEA and C. Norris, 2006. One-to-one technology-enhanced learning: An opportunity for global research collaboration. Research and Practice in Technology Enhanced Learning, 1(0 1): 3-29.Available at: https://doi.org/10.1142/s1793206806000032.

Chen, I.Y.L., S.J.H. Yang and J. Zhang, 2007. Ubiquitous provision of context-aware web services. International Journal of Web Services Research, 4(4): 83-103.Available at: http://doi.org/10.4018/jwsr.2007100104.

Cheung, W.S. and K.F. Hew, 2009. A review of research methodologies used in studies on mobile handheld devices in K-12 and higher education settings. Australasian Journal of Educational Technology, 25(2): 153-183.Available at: https://doi.org/10.14742/ajet.1148.

Crompton, H. and D. Burke, 2018. The use of mobile learning in higher education: A systematic review. Computers and Education, 123(3): 53-64.Available at: http://doi.org/10.1016/j.compedu.2018.04.007.

Hsieh, H.F. and S.E. Shannon, 2005. Three approaches to qualitative content analysis. Qualitative Health Research, 15(9): 12771288. Available at: http://doi.org/10.1177/1049732305276687.

Hung, J.L. and K. Zhang, 2012. Examining mobile learning trends 2003-2008: A categorical meta-trend analysis using text mining techniques. Journal of Computing in Higher Education, 24(1): 1-17.Available at: http://doi.org/10.1007/s 12528-011-9044-9.

Hwang, A.G., C. Tsai, S.J.H. Yang, S. Journal, U.L. April, G. Hwang and S.J.H. Yang, 2008. International forum of educational technology \& society criteria, strategies and research Issues of Context-Aware Ubiquitous Learning Published by : International forum of educational technology \& society linked references are available on JSTOR for this. Journal of Educational Technology \& Society, 11(2): 81-91.

Hwang, G.-J. and P.-H. Wu, 2014. Applications, impacts and trends of mobile technology-enhanced learning: A review of $2008-2012$ publications in selected SSCI journals. International Journal of Mobile Learning and Organisation, 8(2): 83-95.

Hwang, G.J. and C.C. Tsai, 2011. Research trends in mobile and ubiquitous learning: A review of publications in selected journals from 2001 to 2010. British Journal of Educational Technology, 42(4): E65-E70.Available at: http://doi.org/10.1152/ajpgi.00350.2012.

Jagušt, T., I. Botički and H.J. So, 2018. A review of research on bridging the gap between formal and informal learning with technology in primary school contexts. Journal of Computer Assisted Learning, 34(4): 417-428.Available at: https://doi.org/10.1111/jcal.12252.

Looi, C.K., P. Seow, B. Zhang, H.J. So, W. Chen and L.H. Wong, 2010. Leveraging mobile technology for sustainable seamless learning: A research agenda. British Journal of Educational Technology, 41(2): 154-169.Available at: http://doi.org/10.1111/j.14678535.2008.00912.x.

Looi, C.K., L.H. Wong, H.J. So, P. Seow, Y. Toh, W. Chen and E. Soloway, 2009. Anatomy of a mobilized lesson: Learning my way. Computers and Education, 53(4): 1120-1132.Available at: http://doi.org/10.1016/j.compedu.2009.05.021.

Marinagi, C., C. Skourlas and P. Belsis, 2013. Employing ubiquitous computing devices and technologies in the higher education classroom of the future. Procedia-Social and Behavioral Sciences, 73: 487-494.Available at: https://doi.org/10.1016/j.sbspro.2013.02.081.

Pegrum, M., G. Oakley and R. Faulkner, 2013. Schools going mobile: A study of the adoption of mobile handheld technologies in Western Australian independent schools. Australasian Journal of Educational Technology, 29(1): 66-81.Available at: http://doi.org/10.1234/ajet.v29i1.64.

Petticrew, M. and H. Roberts, 2006. Systematic reviews in the social sciences: A practical guide. Malden, MA: Blackwell Publishing Ltd.

Sad, S.N., A. Ilhan and S. Pocan, 2016. Seamless learning: Seamless learning: A compilation study.

Schreier, M., 2012. Qualitative content analysis in practice. Thousand Oaks, CA: Sage.

Scopus, 2018. The world of scientific research is more demanding than ever before. Available from https://www.elsevier.com/solutions/scopus [Accessed July 18, 2018].

Sharples, M., 2015. Seamless learning despite context. In L.-H. Wong, M. Milrad, \& Marcus Specht (Eds.), Seamless Learning in the Age of Mobile Connectivity. Singapore: Springer. pp: 41-56.

Song, Y., 2014. Bring your own device (BYOD) for seamless science inquiry in a primary school. Computers \& Education, 74: 5060.Available at: https://doi.org/10.1016/j.compedu.2014.01.005.

Song, Y., L.H. Wong and C.K. Looi, 2012. Fostering personalized learning in science inquiry supported by mobile technologies. Educational Technology Research and Development, 60(4): 679-701.Available at: http://doi.org/10.1007/s11423-012-9245-6.

Virtanen, M.A., E. Haavisto, E. Liikanen and M. Kääriäinen, 2017. Ubiquitous learning environments in higher education: A scoping literature review. Education and Information Technologies, 23(2): 985-998.Available at: https://doi.org/10.1007/s10639-017-9646-6.

Virtanen, M.A., M. Kääriäinen, E. Liikanen and E. Haavisto, 2017. Use of ubiquitous $360^{\circ}$ learning environment enhances students' knowledge in clinical histotechnology: A quasi-experimental study. Medical Science Educator, 27(4): 589-596.Available at: https://doi.org/10.1007/s40670-017-0429-x.

Wilson, V., 2011. Research methods: Content analysis. Evidence Based Library and Information Practice, 6(4): 177-179.Available at: http://doi.org/10.1177/0165551504044668.

Wong, L.H., 2012. A learner-centric view of mobile seamless learning. British Journal of Educational Technology, 43(1): 19-23.Available at: http://doi.org/10.1111/j.1467-8535.2011.01245.x.

Wong, L.H., W. Chen and M. Jan, 2012. How artefacts mediate small-group co-creation activities in a mobile-assisted seamless language learning environment? Journal of Computer Assisted Learning, 28(5): 411-424.Available at: http://doi.org/10.1111/j.13652729.2011.00445.x.

Wong, L.H., C.K. Chin, C.L. Tan and M. Liu, 2010. Students' personal and social meaning making in a Chinese idiom mobile learning environment. Educational Technology \& Society, 13(4): 15-26.

Wong, L.H. and C.K. Looi, 2010 . Vocabulary learning by mobile-assisted authentic content creation and social meaning-making: Two case studies. Journal of Computer Assisted Learning, 26(5): 42 1-433.Available at: http://doi.org/10.1111/j.1365-2729.2010.00357.x.

Wong, L.H. and C.K. Looi, 2011. What seams do we remove in mobile-assisted seamless learning? A critical review of the literature. Computers and Education, 57(4): 2364-2381.Available at: http://doi.org/10.1016/j.compedu.2011.06.007.

Wu, P.-H., G.-J. Hwang and W.-H. Tsai, 2013. An expert system-based context-aware ubiquitous learning approach for conducting science learning activities. Educational Technology \& Society, 16(4): 217-230.

Wu, W.-H., Y.-C.J. Wu, C.-Y. Chen, H.-Y. Kao, C.-H. Lin and S.-H. Huang, 2012. Review of trends from mobile learning studies: A metaanalysis. Computers \& Education, 59(2): 817-827.Available at: https://doi.org/10.1016/j.compedu.2012.03.016. 